\title{
HUBUNGAN KETERLIBATAN PAMONG DALAM PENGAMBILAN KEPUTUSAN DAN KOMUNIKASI INTERPERSONAL DENGAN MOTIVASI KERJA PAMONG PAKET C DI BPKB PROVINSI GORONTALO
}

\author{
Abdul Rahmat \\ Universitas Negeri Gorontalo, Jl. Jendral Soedirman no. 06 \\ e-mail: infoelmiaumar@gmail.com
}

\begin{abstract}
The core issues have been examined in this study including the relationships of the teacher's involvement in decision making, interpersonal communication, and work motivation of the BPKB teachers in Gorontalo Province. This study used survey method with correlation techniques. The sample was the whole population of the 47 teachers by using total sampling or sample saturated. Based on the analysis of data concluded results namely 1) there is a positive relationship between teacher's involvements in decision-making with the work motivation. 2) There is a positive relationship between interpersonal communication and the work motivation of teachers, 3) There is a positive relationship between involvement in decision-making and interpersonal communication simultaneously on the work motivation of teachers. These results indicated that the higher of teachers' involvement in decision-making and interpersonal communication, the work motivation is increasing.
\end{abstract}

Keywords: involvement, decision making, interpersonal communication, work motivation.

\begin{abstract}
Abstrak
Isu-isu utama dalam penelitian ini mengenai keterlibatan guru dalam pengambilan keputusan, komunikasi interpersonal, dan motivasi kerja guru di BPKB Provinsi Gorontalo. Penelitian ini menggunakan metode survey dengan teknik korelasional dengan menggunakan total populasi sebagai sampel sebanyak 47 guru. Berda-sarkan hasil analisis data diperoleh hasil yakni 1) terdapat hubungan positif antara keterlibatan dalam pengambilan keputusan dengan motivasi kerja guru. 2) Ada hubungan positif antara komunikasi interpersonal dengan motivasi kerja guru, 3) Terdapat hubungan yang positif antara keterlibatan dalam pengambilan keputusan dan komunikasi interpersonal secara bersama-sama terhadap motivasi kerja guru. Hal ini menunjukkan semakin tinggi keterlibatan guru dalam pengambilan keputusan dan komunikasi interpersonal maka motivasi kerja guru juga semakin meningkat.
\end{abstract}

Kata kunci: keterlibatan, pengambilan keputusan, komunikasi interpersonal, motivasi kerja.

\section{PENDAHULUAN}

Dalam proses pengambilan keputusan, kepala Balai Pengembangan Kegiatan Belajar (BPKB) selaku pimpinan seyogyanya memberikan kesempatan kepada para pamong untuk terlibat dan berpartisipasi dalam pengambilan dan penetapan putusan. Pemberian kesempatan untuk terlibat dalam pengambilan keputusan ini merupakan suatu hal yang harus ditempuh oleh kepala $\mathrm{BPKB}$, mengingat posisi dan peran pamong di BPKB merupakan titik sentral yang turut menentukan kualitas pendidikan dan pembelajaran yang dilaksanakan di BPKB. Pelibatan pamong dalam proses pengambilan dan penetapan keputusan di
BPKB dapat dilakukan dengan berbagai cara, antara lain melibatkan pamong dalam menentukan prosedur penerimaan warga belajar baru, pengambilan keputusan tentang langkah-langkah yang harus ditempuh dalam menyesuaikan diri dengan kurikulum baru, dan masih banyak lagi contoh lainnya. Dengan dilibatkannya pamong dalam kegiatan-kegiatan ini dapat mendorong terciptanya iklim dan lingkungan kerja yang positif, memperat hubungan emosi-onal dan hubungan sosial antar sesama, bahkan dapat menjadi sarana menyatukan berbagai pendapat atau persepsi yang berbeda.

Komunikasi interpersonal merupakan suatu bentuk komunikasi dimana 
seseorang terlibat dalam kegiatan komunikasi dengan bertatap muka dengan seseorang atau dengan sekelompok orang lainnya. Kemampuan berkomunikasi secara interpersonal merupakan suatu aktifitas yang memerlukan proses untuk dapat sampai pada komunikasi yang efektif. Kemampuan komunikasi interpersonal menuntut seseorang untuk mampu 'mendengarkan' orang lain. Kemampuan komunikasi interpersonal yang baik memungkinkan kita dapat bekerja secara lebih efektif dalam tim atau kelompok baik dalam situasi formal, informal maupun dalam situasi sosial. Komunikasi interpersonal juga dapat membangun hubungan yang kuat dengan orang lain dan menuntun kita pada kemampuan berkomunikasi dengan lebih baik dengan pemahaman yang lebih baik pula.

Kemampuan komunikasi interpersonal yang baik yang dimiliki oleh seorang pamong dianggap dapat memberikan dampak bagi meningkatnya motivasi kerja pamong. Motivasi merupakan suatu kekuatan potensial yang ada pada diri seseorang manusia, yang dapat dikembangkannya sendiri, atau dikembangkan oleh sejumlah kekuatan luar yang pada intinya sekitar imbalan moneter, dan imbalan non moneter, yang dapat mempengaruhi hasil kinerjanya secara positif atau negatif, hal mana tergantung pada situasi dan kondisi yang dihadapi orang yang bersangkutan Motivasi juga bukan merupakan hal yang mudah dilakukan, karena seorang pimpinan sulit untuk mengetahui kebutuhan (needs) dan keinginan (wants) yang diperlukan oleh seorang bawahan dalam menyelesaikan pekerjaannya.

Motivasi bukan timbul dari dalam diri manusia saja melainkan juga dari kekuatan-kekuatan lingkungan yang mempengaruhi individu untuk melakukan sesuatu berdasarkan tujuan tujuan yang telah ditetapkan sebelumnya untuk dicapai. Dorongan tersebut dapat berdampak positif maupun negatif bagi individu kalau tidak diarahkan, baik oleh diri sendiri maupun orang lain.

\section{TINJAUAN PUSTAKA}

\section{Keterlibatan Pamong dalam Pengam- bilan Keputusan \\ Menurut Davis dan Newstrom} (2000: 179), keterlibatan didefinisikan sebagai keterlibatan mental dan emosional orang-orang dalam situasi kelompok yang men-dorong untuk memberikan kontribusi kepada tujuan kelompok dan berbagai tanggung jawab dalam mencapai tujuan tersebut. Ada tiga gagasan penting dalam definisi itu yakni keterlibatan, kontribusi dan tanggung jawab. Keterlibatan mental dan emosional dimaksudkan sebagai keterlibatan psikologis dan egonya yang melebihi keterlibatan fisik. Seseorang pamong yang aktif mengikuti rapat-rapat, pertemuan, selalu dimintai pendapat atasan sementara atasannya adalah pemimpin otokratik maka keterlibatan yang demikian bukanlah keterlibatan. Seseorang yang berketerlibatan berarti orang tersebut termotivasi untuk memberikan kontribusi, yang diwujudkan dalam bentuk menyalurkan sumber inisiatif dan kreativitasnya guna mencapai tujuan organisasi. lebih dari itu seseorang yang berketerlibatan akan terdorong untuk menerima tanggung jawab dalam aktivitas kelompok. Pada saat orang-orang mulai menerima tanggung jawab aktivitas kelompok maka mereka melihat adanya peluang untuk melakukan hal-hal yang mereka inginkan, yaitu merasa bertanggung jawab menyelesaikan pekerjaannya.

Dalam pandangan Brown dan Moberg (2000:483), keterlibatan merupakan proses di mana dua orang atau lebih saling memperngaruhi dalam membuat keputusan, yang akan berguna pada waktu mendatang. Lebih lanjut dijelaskan bahwa dalam proses keterlibatan terkandung tiga hal mendasar, yakni pengarahan (direction), konsultasi (consultation) dan delega-si (delegation). Dalam memutuskan suatu hal pemimpin memberikan kesempatan kepada bawahan untuk memberikan ma-sukan namun pada ini keputusan masih berada ditangan pimpinan. Apabila atasan mengijinkan 
bawahan untuk mengambil keputusan sendiri, maka tingkat yang demikian termasuk delegasi. Pada tingkat ini diperlukan bawahan yang benar-benar menguasai tugas, bertanggung jawab, memiliki kemampuan yang handal dan memiliki pengalaman sehingga tugas yang didelegasikan dapat diselesaikan dengan sebaik-baiknya. Proses keterlibatan disajikan pada gambar 1 berikut:

\begin{tabular}{|l|} 
Pengarahan Konsultasi Delegasi \\
\hline Pertisipasi Rendah Pertisipasi Tinggi
\end{tabular}

Gambar 1. Proses Keterlibatan

\section{Sumber : Warren W. Brown dan Dennis J. Moberg, Organization Theory and Management (New York: John Wiley and Sons, 2000), p. 483}

Keterlibatan adalah pembagian dan keikutsertaan dalam proses pembuatan keputusan kelompok. Keterlibatan yang dimaksud berkaitan dengan siapa, apa, kapan, di mana dan bagaimana. Defenisi tersebut sejalan dengan apa yang dikemukakan oleh Siagian bahwa pimpinan organisasi bersedia melibatkan bawahannya dalam proses pengambilan keputusan bukan hanya yang menyangkut diri sendiri, seperti pekerjaan, jabatan dan penghasilan tetapi mengenai semua aspek kehidupan kekaryaan dalam organisasi. Hal ini dapat dimengerti karena pamong belajar tidak mau lagi diperlakukan sebagai alat produksi semata, melainkan ingin turut serta memainkan peranan yang lebih besar dalam pengelolaan organisasi di mana mereka berkarya (Siagian, 2005: 130).

Pendapat tersebut di atas diperkuat oleh Longenecker (1969: 433), di mana keterlibatan pamong belajar merupakan cara yang demokratis dan berusaha untuk melibatkan bawahan secara langsung dalam kegiatan bisnis. Bawahan diikutsertakan dalam kepentingan organisasi dalam memikul tanggung jawab sesuai dengan tingkat kematangannya. Bawahan juga diizinkan dan didorong untuk berketerlibatan dalam berbagai aspek dari pengambilan keputusan atasannya yang biasanya tidak diharapkan dan tidak boleh ditoleransi dalam banyak organisasi. Salah satu bentuk keterlibatan sebagaimana dimaksud di atas misalnya atasan meminta bawahan untuk memberikan saran atau ide dalam menangani permasalahan yang dihadapi.

Keterlibatan juga didefinisikan sebagai proses di mana para pamong belajar mempengaruhi dan ikut mengendalikan dengan mengembangkan inisiatif dan keputusan serta sumber-sumber yang mempengaruhinya. Dengan mempengaruhi pengambilan keputusan berarti pamong belajar telah ikut meletakkan kepentingannya dan hal itu sangat wajar demi komitmen dan tanggung jawab. Dengan melakukan pengendalian maka pamong belajar tidak lagi dipandang sebagai obyek tetapi perannya diakui. Tingkat ketepatan keterlibatan tergantung tidak hanya pada keberadaan hubungan antar pribadi dalam organisasi tetapi juga situasi di mana organisasi itu dijalankan (Scanlon \& Bernard, 2003: 97).

Keterlibatan menurut Schermerhorn (2006: 340), diwujudkan dalam bentuk bekerja bersama-sama menanggapi dan menaruh perhatian terhadap sasaran maupun tujuan organisasi. Anthony, seperti dikutip oleh Sutarto (2003: 43), menambahkan, apabila para manajer dan bawahan sama-sama menanggung wewenang, pengaruh sinergetik akan timbul, artinya dalam kesatuan ada kekuatan. Dikemukakan pula bahwa pada umumnya beberapa otak lebih baik daripada satu otak. Apalagi dengan semakin luas dan banyaknya jenis pekerjaan para pimpinan sering tidak mengetahui apa yang dikerjakan bawahannya maka sumbangan pemikiran dari orangorang yang lebih mengetahui pekerjaan dengan segala permasalahannya merupakan sesuatu yang sangat penting bagi pengambilan keputusan. Sementara itu para bawahan tidak hanya menunggu 
perintah, tetapi sudah mulai mencari tugas. Para bawahan dapat diajak bersama-sama memikirkan berbagai masalah yang dihadapi organisasi dan dapat diajak bersama-sama membuat keputusan. Pada tingkat kematangan yang demikian maka bawahan seharusnya dilibatkan dalam manajemen (Sutarto, 2003: 143-144).

Ada tiga hal penting yang ada hubungannya dengan keterlibatan pamong belajar dalam pengambilan keputusan yaitu: kontrol, motivasi dan pembelajaran. Selanjutnya keterlibatan pamong belajar dalam pengambilan keputusan akan memunculkan dorongan dan motivasi dalam hal inovasi dan performance. Sedangkan dalam hal pembelajaran keterlibatan akan memungkinkan terjadinya pembelajaran dan pengembangan di kalangan pamong belajar di samping dapat meningkatkan kerjasama diantara sesama pamong, dengan pamong dalam hal kurikulum dan tugas-tugas lainnya (Smyle, 2006: 181: 189).

Berdasarkan teori-teori di atas dapatlah disimpulkan bahwa yang dimaksud dengan keterlibatan pamong belajar dalam pengambilan keputusan adalah penilaian pamong belajar terhadap peran sertanya baik secara mental maupun emosional dalam memberikan kontribusi kepada BPKB dalam proses pengambilan keputusan, dengan indikasi: turut menetapkan tujuan, memberikan saran atau pendapat, bertanggung jawab, menggunakan wewenang, dan turut menyelesaikan masalah.

\section{Komunikasi Interpersonal}

Sesuai dengan kodratnya manusia tidak bisa hidup tanpa orang lain. Sebagai makhluk sosial, setiap manusia memerlukan kehadiran manusia lain untuk berkomunikasi, berkelompok, saling bantumembantu dalam memenuhi kebutuhannya. Usaha manusia untuk memenuhi kebu-tuhannya itu tidak bisa dilakukan sendiri, sehingga memerlukan bantuan dan kerja sama dengan orang lain. Kondisi demikian mengharuskan manusia berkomunikasi antara yang satu dengan lainnya dalam lingkungan kelompok maupun dalam kehidupan bermasyarakat yang luas. Komunikasi antar individu yang disebut juga komunikasi interpersonal akan berlangsung efektif dan efisien apabila setiap individu menghormati dan mematuhi norma dan nilai-nilai yang mengatur perilakunya dalam berkomunikasi dengan peran masing-masing dalam kelompoknya. Komunikasi adalah inti dari sebuah interaksi sosial. Tidak mungkin melakukan interaksi sosial tanpa komunikasi. Sejak bangun tidur sampai menjelang tidur manusia berkomunikasi dengan orang lain termasuk dengan anggota keluarga, teman sekerja, pimpinan, relasi dan seterusnya. Komunikasi inter-personal akan berhenti pada saat tidur.

Baron (2003: 489), mendefinisikan bahwa komunikasi dalam proses di mana orang, kelompok atau organisasi mengirimkan beberapa informasi kepada orang, kelompok atau organisasi lainnya. Komunikasi akan berhasil apabila pesan yang disampaikan komunikator cocok dengan pengalaman dan pengertian yang diperoleh komunikan. Jika pengalaman komunikator sama dengan pengalaman komunikan maka komunikasi akan berjalan dengan lancar. Lebih lanjut dinyatakan bahwa komuikator yang berpengalaman akan selalu menaruh perhatian kepada arus balik dan selalu mengubah cara penyampaian pesannya sesuai dengan tanggapan komunikan. Tanggapan arus balik berguna untuk mengontrol sukses tidaknya proses komunikasi. Untuk melaksanakan komunikasi menjadi efektif terdapat dua faktor penting pada diri komunikator, yakni kepercayaan (source credibility) dan daya tarik (source atractiveness).

Menurut Hovland, Janis dan Kelly seperti yang dikutip oleh Rakhmat, (2008:3), komunikasi didefinisikan sebagai proses dengan mana seseorang (komunikator) mengirim stimuli (biasanya verbal) untuk mengubah perilaku orang lain (the audience). Sementara 
Dance mengartikan komunikasi dalam kerangka psikologi behaviorisme sebagai usaha menimbulkan respons melalui lambang-lambang verbal, ketika lambanglambang verbal tersebut bertindak sebagai stimuli. Pendapat dari Kenneth dan Gary (dalam Umar, 2008: 25-26), mendefinisi-
Komunikasi dalam kegiatannya berlangsung melalui proses yaitu jalan atau urutan kegiatan sehingga timbul pengertian tentang suatu hal diantara unsur-unsur yang berkomunikasi. Bila unsur-unsur yang terlibat tersebut dapat berperan dengan baik maka komunikasi dapat ber-

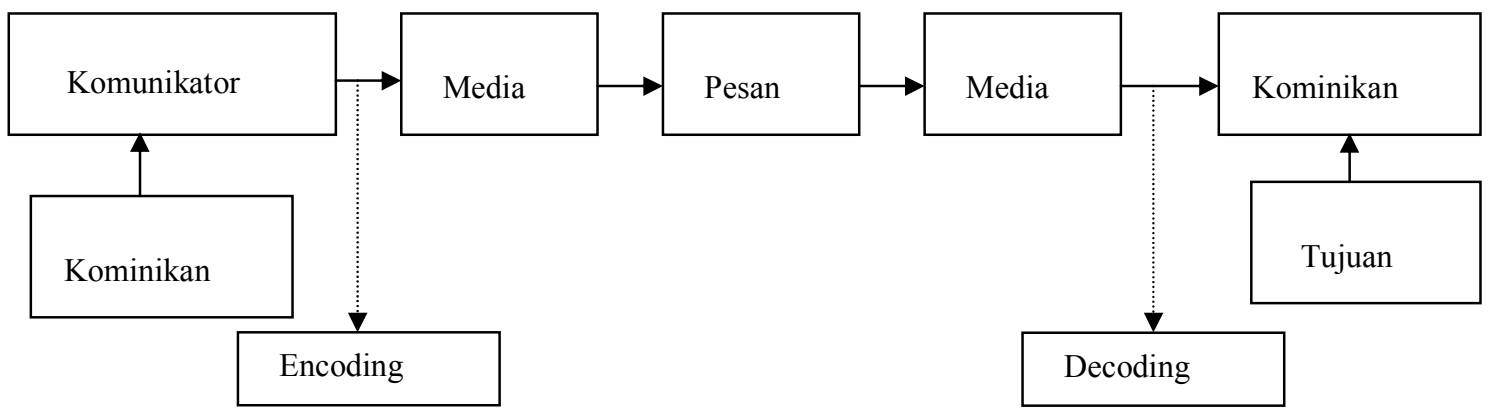

Gambar 2. Proses Komunikasi

kan komunikasi sebagai penyampaian informasi antara dua orang atau lebih yang juga meliputi pertukaran informasi antara manusia dan mesin.

Definisi ini mengisyaratkan bahwa komu-nikasi setidaknya mengandung tiga gaga-san yakni (1) adanya informasi atau pesan yang akan dikirim, (2) adanya pengirim dan (3) penerima. Pengirim atau penerima dapat berupa manusia atau mesin. Pengirim pesan disebut juga sumber informasi. Dalam suatu organisasi pengi-rim pesan dapat diperankan oleh pimpinan yang sedang mengkomunikasikan gagasan-gagasan kepada para bawahan, sedangkan penerima pesan dapat diperankan oleh seseorang yang baru mendapat penjelasan-penjelasan sehubungan dengan tugasnya yang baru. Lebih lanjut dikemukakan bahwa komunikasi dalam organisasi dapat dilihat dari sisi komunikasi antarpribadi dan komunikasi organisasi. Komunikasi dapat terjadi karena adanya komponen-komponen, yaitu komunikator yang mengirim pesan (encoded) melalui lambang dalam bentuk bahasa. Selanjutnya pesan disampaikan melalui media dan akhirnya pesan ditrima oleh penerima (recipient) dan selanjutnya pesan tersebut ditafsirkan (decoded) (Rakhmat, 2008: 6). langsung secara efektif.

Unsur-unsur pada proses komunikasi sebagaimana terlihat pada gambar 2 berikut:

Sumber : Santoso Sastropoetro, Pendapat Publik, Pendapat Umum, dan Pendapat Khalayak dalam Komunikasi Sosial (Bandung: Remaja Rosda Karya, 2000), pp. 7-8

Suatu komunikasi dapat dikatakan berhasil apabila diantara penyebar pesan dan penerima pesan terdapat pengertian yang sama terdapat isi pesan. Isi pesan disampikan oleh penyebar pesan melalui lambang-lambang atau simbol-simbol tertentu. lambang atau simbol yang dipergunakan untuk berkomunikasi dapat berupa: (1) bahasa baik lisan maupun tulisan, (2) isyarat-isyarat, (3) gambargambar dan (4) tanda-tanda (Sastropoetro, 1990: 7-8).

Komunikasi yang efektif menurut Tubbs dan Moss (dalam Sastropoetro, 1990: 13), paling tidak menimbulkan lima hal: pengertian, kesenangan, pengaruh pada sikap, hubungan yang makin baik dan tindakan. Pertama menimbulkan pengertian, artinya penerimaan yang cermat dari isi stimuli seperti yang dimaksud oleh komunikator. Namun tidak semua komunikasi ditujukan untuk menyampaikan infor- 
masi dan membentuk pengertian. Kedua, apabila kita mengucapkan, "selamat pagi, apa kabar?" Maka komunikasi yang dilakukan untuk menimbulkan kesenangan. Ketiga, paling sering komunikasi dilakukan untuk mempengaruhi sikap orang lain, sehingga disebut komunikasi persuasif.

Dalam komunikasi persuasif diperlukan pemahaman tentang faktor-faktor pada diri komunikator dan pesan yang menimbulkan efek pada komunikan. Persuasi sendiri adalah proses mempengaruhi pendapat, sikap dan tindakan orang menggunakan manipulasi psikologi sehingga orang tersebut bertindak seperti atas kehendaknya sendiri. Keempat, komunikasi juga ditujukan untuk menumbuhkan hubungan sosial yang baik. Hal ini karena manusia adalah mahluk sosial yang tidak dapat hidup sen-diri, sehingga setiap manusia ingin berhubungan orang lain secara positif. Kelima, efektifitas komunikasi dapat diukur dari tindakan nyata yang dilakukan oleh komunikate yaitu orang yang menerima komunikasi.

Komunikasi pada dasarnya adalah penyampaian pesan yang bermakna dari sumber oleh komunikator kepada komunikan sebagai alamat. Dalam hal ini Effendi (2006; 34), menyatakan bahwa bila seseorang berkomunikasi dengan orang lain maka mereka sebenarnya baru mengadakan "kesamaan" satu sama lainnya. Komunikasi pada hakikatnya adalah hubungan antara komunikator dengan komunikan yang sama-sama sesuai untuk suatu pesan tertentu.

Miller dan Stenberg lewat Tubbs dan Moss memperkenalkan beberapa konsep penting berkaitan dengan kualitas hubungan antar personal.

Pertama, dalam hubungan kualitas tinggi informasi tentang orang lain lebih bersifat psikologis daripada bersifat kultural dan sosiologis. Informasi yang bersifat kultural sosiologis seperti gender, usia, pekerjaan, keanggotaan dalam suatu kelompok dan sebagainya dapat dilakukan tanpa mengenali orang tersebut secara dekat. Lain halnya dengan informasi tentang diri seseorang secara psikologis seperti apa yang disukai (hobi) atau

yang tidak disukai, cita-cita, hal-hal yang ditakutkan, hari ulang tahun dan sebagainya akan membutuhkan hubungan yang lebih dekat atau berkualitas.

Kedua, aturan-aturan hubungan kualitas tinggi lebih banyak disepakati dan dikembangkan oleh kedua orang yang terlibat didalamnya. Sebagai contoh aturan bahwa sebelum bertamu harus menelpon dahulu menjadi tidak berlaku karena kualitas hubungan yang sudah baik dan dapat datang kapan saja, boleh menelpon walaupun dimalam buta dan seterusnya.

Ketiga, peranan dalam hubungan antarpersonal pada pokoknya lebih ditentukan oleh karakter pribadi dari pada oleh situasi, misalnya seorang suami lebih biasa menangani belanja mingguan dan membersihkan rumah sementara istrinya selalu mengurus dan mengatur perbaikan rumahnya. Keempat, hubungan berkualitas lebih menekankan pilihan perseorangan dari pada pilihan kelompok. Pilihan perseorangan lebih bersifat informasi psikologis bukan pilihan berdasarkan apa yang dimili-ki kelompoknya, artinya pilihan perse-orangan tidak akan terpengaruh dan berubah walaupun orang tersebut pindah kelompok (Tubbs dan Moss, 2006: 11-12).

Gouran, Miller dan Wiethoff (20022: 140), mendefinisikan komunikasi interpersonal adalah interaksi anrtara seseorang dengan orang lain dalam beberapa waktu dimana keduanya saling beradaptasi sebagai individu yang unik. Ketiga ahli ini memandang bahwa komunikasi interpersonal adalah komunikasi yang unik dan berbeda dengan komunikasi yang lain karena: (1) ada beberapa partisipan yang terlibat, (2) interaksi yang terjadi sangat dekat, (3) interaksinya dapat dengan meihat, mendengar, menyentuh, tersenyum dengan melalui beberapa saluran, dan (4) umpan balik dapat terjadi segera. Komunikasi interpersonal juga diartikan sebagai komunikasi yang terjadi antara orang- 
orang yang telah saling kenal dan berlangsung kapan saja.

Pendapat lain dikemukakan oleh Pareek (2006: 143-144), yang mendefinisikan komunikasi interpersonal sebagai pemberian pesan-pesan yang berorientasi tujuan antara dua orang atau lebih melalui suatu medium atau media. Lebih jauh Pareek menambahkan bahwa komunikasi adalah proses yang terdiri dari beberapa unit. Unit pokok dari komunikasi adalah tindakan komunikasi, yaitu pengiriman suatu pesan yang berorientasikan tujuan melalui suatu medium atau media, dari seseorang kepada orang lain yang menerima pesan tersebut. Unsur-unsur dalam definisi ini adalah: (1) pengiriman, (2) alamatnya, (3) pesannya (dikirimkan) (4) maksud pesan, dan (5) medium-nya.

Seiler (2002; 343-344) mendefinisikan komunikasi interpersonal sebagai pertukaran informasi di antara dua orang atau lebih yang terbangun relasi dengan yang lain. Sedangkan Curtis, Floyd dan Winsor (2002: 26), mengemukakan bahwa komunikasi interpersonal adalah komunikasi yang terjadi antara dua orang atau lebih yang berlangsung secara alami dan mampu menghasilkan hubungan yang produktif.

Pendapat lainnya dikemukakan oleh Gito Sudarmo dan Sudita (2000: 201-203), yang mengartikan komunikasi antarpribadi adalah pertukaran informasi yang terjadi diantara dua orang. Menurut kedua ahli ini dalam melakukan komunikasi antar pribadi masing-masing memiliki cara sendirisendiri dalam berhubungan dengan orang lain.

Menurut Johnson seperti yang dikutip oleh Supratiknya sekurangkurangnya ada empat peranan yang disumbangkan oleh komunikasi antarpribadi dalam rangka menciptakan kebahagiaan manusia dalam kehidupannya.

Pertama, komunikasi antarpribadi dapat membantu perkembangan intelektual dan sosial kita. Perkembangan manusia sejak bayi sampai mengikuti pola semakin meluasnya ketergantungan kita dengan orang lain. Bersamaan dengan itu perkem- bangan intelektual kita ditentukan oleh kualitas komunikasi dengan orang lain.

Kedua, identitas atau jati diri seseorang akan terbentuk dalam dan lewat komunikasi. Selama berkomunikasi sadar atau tidak sesoerang akan mengamati, memperhatikan tanggapan-tanggapan yang diberikan oleh orang lain kepadanya. Dari komunikasi itu seseorang akan menemukan jati dirinya. Ketiga, dalam rangka memahami realitas di sekeliling kita serta menguji kebenaran kesan-kesan dan pengertian yang kita miliki tentang dunia di sekitar kita perlu membandingkannya dengan kesan-kesan dan pengertian orang lain tentang realitas yang sama. Pembandingan sosial (social comparison) semacam itu hanya dapat dilakukan melalui komunikasi dengan orang lain.

Keempat, kesehatan mental seseorang sebagian besar ditentukan oleh kualitas komunikasi atau hubungannya dengan orang lain. Lebih-lebih orangorang yang merupakan tokoh-tokoh signifikan (significant figures) dalam hidup kita. Bila hubungan kita dengan orang lain diliputi berbagai masalah maka tentu kita akan menderita, merasa sedih, cemas dan tersiksa. Bila dengan begitu kita menarik diri dalam pergaulan dan menghindar dengan orang lain maka rasa sepi dan terasing yang mungkin kita alami akan menimbulkan penderitaan tidak hanya penderitaan batin dan emosional tetapi juga penderitaan fisik.

Jendela Johari (Johari Window), istilah ini diambil dari nama depan dua orang psikologi yang mengembangkan konsep ini yakni Joseph Luft dan Harry Ingham. Pada pokoknya konsep ini menawarkan cara melihat kesaling bergantungan interpersonal dan antar personal. Gambar 3 melukiskan empat kondisi ketika seseorang berinteraksi dengan orang lain dalam bentuk empat kuadran mirip empat kaca pada sebuah jendela. Informasi yang diketahui dan tidak diketahui baik oleh diri sendiri maupun orang lain. 
Pembagian kuadran berdasarkan kesadaran diri sendiri dan diri orang lain.

\begin{tabular}{lcc} 
& \multicolumn{2}{c}{ DIRI SENDIRI } \\
\cline { 2 - 3 } & Tidak Tahu & Tahu \\
\cline { 2 - 3 } Tahu & 1 & 2 \\
ORANG & Daerah Terbuka & Daerah Buta \\
\cline { 2 - 3 } LAIN & 3 & 4 \\
Tidak Tahu & Daerah & Daerah Tak \\
& Tersembunyi & Sadar \\
\cline { 2 - 3 } & &
\end{tabular}

Gambar 3. Johari Window

Sumber : Supratiknya, Komunikasi Antarpribadi (Yogyakarta: Kanisius, 2005), pp. 16-17.

Pada daerah ini baik diri sendiri maupun orang lain sama-sama mengetahui atau memilih informasi yang diperlukan sehingga komunikasi dapat terjadi secara efektif.

Komunikasi pada penerapannya dapat dilakukan dalam dua jalur yaitu jalur formal di lingkungan organisasi dan jalur nonformal di dalam pergaulan sosial. Di samping itu komunikasi juga menganut sisitem keatas untuk memperoleh masukan dari bawahan dan sistem komunikasi kebawah yang salah satu fungsinya memberikan informasi dari pimpinan kepada pamong belajar. Peranan komunikasi nampak begitu penting dalam pengelolaan sebuah organisasi. Seorang manajer harus mampu berkomunikasi dengan baik untuk membangun human skill dan menjaga relasi dengan bawahan. Hal ini dilakuakn untuk secara langsung mempengaruhi perilaku dan hubungan dengan para pamong belajar nya melalui komunikasi, bimbingan dan tindakan disiplin.

Komunikasi interpersonal yang telah diuraikan terdahulu, terdapat juga di lingkungan setiap dan semua BPKB sebagai organisasi kerja, baik berupa komunikasi formal maupun komunikasi informal. Komunikasi interpersonal yang bersifat formal berlangsung karena pada setiap BPKB terdapat struktur organisasi yang mengatur posisi dan peran setiap pamong belajar dan personil lainnya dalam melaksanakan tugas pokok masing-masing sebagai bagian dari volume kerja BPKB.

Komunikasi interpersonal formal yang berlangsung sesuai dengan norma yang ditetapkan sebagai peraturan secara resmi itu, sekurang-kurangnya terdiri dari komunikasi ke atas dan ke bawah (vertical communication), komunikasi lateral (horizontal communication) dan komunikasi diagonal (grapevine communication).

Berdasarkan berbagai teori yang telah diuraikan di atas dapat dikemukakan bahwa yang dimaksud dengan komunikasi interpersonal adalah interaksi antara dua individu atau lebih untuk saling menukar informasi baik bersifat formal dalam bentuk komunikasi organisasi maupun bersifat informal dalam bentuk pergaulan sosial yang ditandai dengan penyampaian informasi, intensitas komunikasi, keterbukaan, dan kesesuaian pandangan.

\section{Motivasi Kerja}

Luthan (2005: 141), berpendapat bahwa motivasi adalah proses yang berawal dari kebutuhan psikologis maupun psikis pada diri seseorang sehingga perilaku aktif atau dorongan yang diarahkan pada tujuan maupun insentif. Dalam hal ini motivasi memiliki tiga unsur yang saling berkaitan yakni kebutuhan (need), dorongan (drives) dan perangsang (incentives). Kunci untuk memahami proses motivasi terletak pada makna dan hubungan antar unsur di atas. Huitt (2008: 1) mendefinisikan bahwa motivasi adalah keadaan internal atau kondisi berupa kebutuhan, hasrat atau keinginan yang menggerakkan, menggiatkan dan mengarahkan perilaku.

Berelson dan Steiner, sebagaimana yang dikutip oleh Koontz, Donell dan Weihrich (2004: 478) mendefinisikan motif sebagai keadaan dari dalam yang menggiatkan, menggerakkan atau memindahkan dan secara langsung berhubungan dengan perilaku yang mengarah pada tujuan (goals). Dalam hal ini motif sebenarnya merupakan pendorong yang berasal dari dalam diri seseorang untuk melaksanakan aktivitas-aktivitas yang 
dapat mengarah pada sasaran tertentu. Dengan adanya motif seseorang dapat tergerak untuk bertingkah laku dan berbuat dengan tujuan tertentu. Sementara itu motivasi adalah istilah umum yang berlaku pada seluruh kelompok dari dorongan hasrat, kebutuhan, harapan dan kekuatan lain yang serupa.

Motivasi yang terdapat dalam diri seseorang mempunyai tiga karakteristik, yakni: (1) apa yang menggerakkan perilaku seseorang, (2) apa yang mengarahkan perilaku, dan (3) bagaimana perilaku tersebut dapat dipertahankan. Ketiga komponen di atas sangat penting dan merupakan faktor penentu bagi perilaku seseorang dalam bekerja. Pertama, pengertian ini menitikberatkan kekuatan yang terdapat pada diri seseorang sehingga terdorong untuk berperilaku dengan caracara yang sesuai dengan lingkungan tertentu. Kedua, sebagian orang berperilaku berorientasi tujuan atau perilakunya diarahkan kepada sesuatu tujuan. Ketiga, ada anggapan bahwa motivasi merupakan orientasi sistem di mana kekuatan pada diri seseorang dan lingkungannya memberikan umpan balik untuk memperkuat intensitas dorongan dan tujuannya maupun untuk tidak melakukan aksinya (Steers and Porter, 2005: 6).

Pendapat lain dikemukakan bahwa motivasi adalah kemauan dengan usaha sekuat-kuatnya untuk mencapai tujuan organisasi dan disesuaikan dengan kemampuan untuk memuaskan beberapa kebutuhan diri. Di sini ada tiga kunci yang berhubungan dengan motivasi yaitu usaha, tujuan organisasi dan kebutuhan. Lebih lanjut dikemukakan juga bahwa proses motivasi itu dimulai dari kebutuhan yang tidak terpuaskan, kemudian timbul ketegangan yang merupakan dorongan untuk berperilaku tertentu.

Setelah kebutuhan itu terpenuhi maka ketegangan tersebut akan menurun. Proses motivasi tersebut seperti terlihat pada gambar berikut:

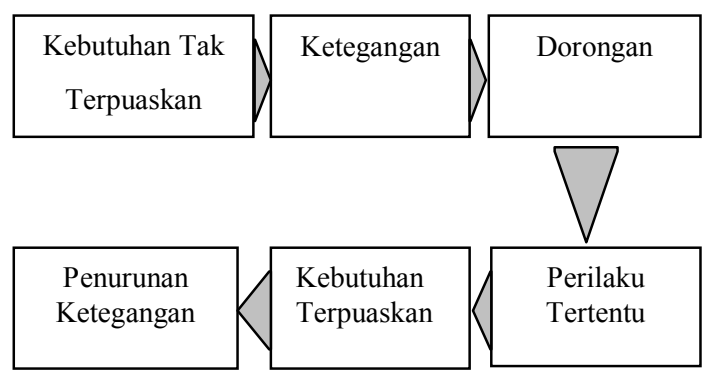

Gambar 4. Proses Motivasi

Sumber: Stephen P. Robinson dan Mary

Coulter, Management (New Jersey:

Prentice Hal International, Inc, 1999), p. 484

Sementara itu Cascio (2005: 416), menuliskan bahwa Teori Motivasi diklasifikasikan menjadi empat bagian, yaitu teori kebutuhan, teori penguatan, teori harapan dan penetapan tujuan. Dalam teori kebutuhan (need theories) motivasi dipandang sebagai kekuatan berupa hasrat seseorang memuaskan kebutuhannya. Teori ini memusatkan perhatian pada faktor-faktor dalam diri seseorang yang menguatkan, mendukung dan menghentikan perilaku seseorang tersebut. Seorang melakukan suatu pekerjaan adalah untuk memenuhi kebutuhan hidupnya baik materil maupun nonmateril. Bila kebutuhannya sudah terpenuhi akan timbul kepuasan yang akan mempertinggi semangat kerjanya. Pada teori kebutuhan diasumsikan bahwa tindakan manusia pada hakikatnya adalah untuk memenuhi kebutuhannya. Oleh karena itu apabila pimpinan akan memotivasi bawahannya haruslah mengetahui apa yang menjadi kebutuhan bawahannya tersebut.

Pada teori penguatan (reinforcement theories) yang disebut juga teori intensif didasarkan pada prinsip pembelajaran yaitu perilaku yang dihargai cenderung diulang dan yang tidak dihargai cenderung tidak diulangi. Teori ini tidak menggunakan konsep suatu motif atau proses motivasi. Sebaliknya pada teori ini dijelaskan bagai-mana konsekuensi perilaku seseorang dimasa lalu akan mempengaruhi tindakannya dimasa yang akan datang 
dalam suatu siklus proses belajar. Menurut Hasibuan (2006: 116), teori ini menyatakan bahwa kekuatan yang memotivasi seseorang untuk bekerja tergantung dari hubungan timbal balik antara apa yang diinginkan dengan hasil pekerjaan itu. Seseorang akan bekerja untuk merealisasikan harapan-harapannya. Bila seseorang merasa yakin bahwa sesuatu yang diharapkan akan terpenuhi maka ia akan mau bekerja keras, dan sebaliknya. Lebih lanjut menurut Hasibuan teori harapan didasarkan atas tiga hal yakni harapan (expectancy), nilai (value) dan pertautan (instrumentality).

Harapan (expectancy) adalah suatu kesempatan yang diberikan akan terjadi karena perilaku. Seseorang akan mengharapkan suatu konsekuensi tertentu dari tingkah lakunya. Harapan ini mempengaruhi keputusanya bagaimana seharusnya bertingkah laku. Misalnya seorang manajer pemasaran akan berpikir melampaui target penjualan mungkin karena mengharapkan bonus, pujian atau promosi jabatan. Besarnya harapan berkisar antara "nol" sampai "positif satu". Harapan dinyatakan dalam kemungkinan atau probabilitas.

Sedangkan nilai (value) adalah akibat dari perilaku tertentu bagi setiap individu yang bersangkutan. Hasil dari tingkah laku tertentu mempunyai valensi khusus, atau kekuatan untuk memotivasi yang bervariasi dari satu individu ke individu lainnya. Sebagai contoh seorang manajer yang berorientasi kepada uang dan prestasi, peralihan jabatan dengan gaji lebih besar dikota lain akan mempunyai valensi lebih besar dari pada seorang manajer yang menghargai ketenangan berkeluarga dengan berkumpul bersama anak istri, pemindahan yang sama akan mempunyai valensi lebih rendah.

Sementara yang disebut pertautan (instrumentality) adalah persepsi dari individu bahwa hasil tingkat pertama akan dihubungkan dengan hasil tingkat kedua. Pertautan juga dapat diartikan besarnya probabilitas artinya seberapa besar kemungkinan terpenuhinya keinginan dan kebutuhannya bila pekerjaannya dilakukan dengan efektif (Hasibuan, 2006: 117).

Dalam teori penetapan tujuan (goalsetting theories) dinyatakan bahwa perilaku seseorang terkait erat dengan tujuannya (Cascio, 2005: 416). Dalam teori penetapan tujuan dinyatakan bahwa tujuan-tujuan yang spesifik dan sukar tetapi diterima oleh yang bersangkutan dapat menjurus kepada prestasi kerja yang lebih tinggi. Kecendurungan seseorang untuk bekerja demi tercapainya tujuan, dapat merupakan sumber motivasi yang besar.

Earley dan Shalley seperti yang diku-tip oleh Stoner, Freeman dan Gilbert J.R. menguraikan bahwa proses penentuan sasaran terbagi dalam empat tahap kesimpulan seseorang.

Pertama, penetapan standar apa yang hendak dicapai. Artinya sebelum seseorang beraktivitas dengan perilaku tertentu ia akan berfikir kemungkinan-kemungkinan dan alternatif mengenai standar apa yang akan dicapai, untuk itu harus ditetapkan terlebih dahulu. Kedua, adanya evaluasi apakah standar tersebut dapat dicapai. Dalam tahap ini seseorang sudah memetakan kemungkinan-kemungkinan dan melakukan perhitungan mengenai kekuatan dan kelemahan dirinya untuk mencapai standar yang telah ditetapkan sebelumnya. Ketiga, pada tahap ini evaluasi dilakukan sekali lagi, yaitu evaluasi menyangkut apakah standar yang sudah ditetapkan tersebut sesuai dengan sasaran pribadinya. Keempat, bila ketiga tahap sebelumnya sudah tidak ada masalah artinya standar yang ditetapkan dapat dicapai dan sesuai dengan sasaran pribadi maka seseorang baru akan muncul tingkah laku kearah sasaran (Freeman and Gilbert, 1996: 148).

Chung dan Megginson seperti yang dikutip oleh Gomes (1997: 177- 181), menjelaskan bahwa motivasi dirumuskan sebagai perilaku yang ditujukan pada sasaran. Motivasi terkait erat dengan tingkat usaha yang dilakukan seseorang dalam mengejar tujuan. Kaitannya dengan motivasi seseorang untuk bekerja biasanya 
ditujukan dengan usaha yang terus menerus dan berorientasi pada tujuan, dan tidak mudah terganggu hal-hal kecil. Motivasi seseorang pekerja melibatkan faktor-faktor individual dan faktor-faktor organisasional. Faktor-faktor individual seperti kebutuhan-kebutuhan (needs), tujuantujuan (goals), sikap (attitudes) dan kemampuan-kemampuan (abilities). Sedangkan yang tergolong faktor organisasional meliputi pembayaran (pay), keamanan pekerjaan (job security) sesama pekerja (co-workers), pengawasan (supervision), pujian (praise), dan pekerjaan itu sendiri (job itself.)

Motivasi akan mempengaruhi perilaku seseorang dan perilaku manusia termotivasi dengan adanya keinginan untuk mencapai tujuan, dengan kata lain perilaku manusia selalu berorientasi pada tujuan tertentu (Hersey dan Blanchard, 2009: 18). Pendapat senada juga menyebutkan bahwa motivasi adalah berbagai pengaruh yang menyebabkan, menghubungkan dan mendukung perilaku seseorang. Seseorang akan berperilaku tertentu terkait erat dengan keinginan-keinginannya (Hellriegel dan Slocum, 2009: 424). Hal ini sesuai dengan apa dikemukakan Gibson, Ivancevich dan Donnelly (2001: 99), bahwa motivasi adalah pengertian yang menggambarkan kekuatan tindakan dari pamong dalam memulai dan menggerakkan perilaku. pamong yang dimotivasi oleh pimpinannya akan menemukan cara terbaik dalam melakukan pekerjaannya dan akan menghasilkan barang atau jasa dengan kualitas tinggi daripada pamong yang tidak dimotivasi.

Pada dasarnya perilaku manusia berorientasi pada tujuan serta digerakkan oleh keinginan mencapai tujuan tertentu. Wujud dari setiap perilaku adalah tindakan, artinya bentuk perilaku yang paling nyata adalah tindakan atau aktivitas. Dapat dikatakan bahwa setiap perilaku seseorang adalah serangkaian tindakan atau aktivitas. Perilaku seseorang tidak dapat dilepaskan dari dua unsur utama yaitu motivasi dan tujuan yang saling tergantung satu dengan lainnya. Motivasi merupakan kekuatan dari dalam diri seseorang, sedangkan tujuan adalah sesuatu yang hendak dicapai yang berada di luar diri seseorang. Dalam kaitan ini kadang-kadang istilah motivasi dipakai silih berganti dengan istilah lainnya seperti: kebutuhan (need), keinginan (want), dorongan (drive), atau impulsa (Thoha, 2004: 200-202).

Motivasi sangat berpengaruh pada intensitas tindakan dan kerja seseorang, motivasi merupakan hasrat seseorang untuk melakukan pekerjaan paling baik atau menggunakan usaha maksimum dalam mengerjakan tugas yang ditetapkan. Seseorang yang memiliki motivasi tinggi akan bekerja sebaik-baiknya disertai dengan usaha yang sungguh-sungguh demi hasil yang memuaskan.

Motivasi juga mendorong manusia untuk bekerja. Dalam hal ini Anoraga (2002: 35), mengatakan bahwa motivasi adalah sesuatu yang menimbulkan semangat atau dorongan kerja. Dorongan dan semangat ialah yang membuat seseorang tidak mudah menyerah dan tetap bertahan pada perilaku tertentu untuk mencapai sesuau yang diinginkan.

Menurut pandangan Amstrong (2009: 65), motivasi merupakan sesuatu yang mampu menggerakkan seseorang untuk bertindak atau berperilaku menurut cara-cara tertentu. Motivasi dapat dibedakan menjadi dua bentuk yakni motivasi hakiki (instrinsic) dan motivasi (ekstrinsik). Motivasi instrinsic adalah motivasi yang berasal dari dalam diri individu itu sendiri yang merupakan faktor-faktor dari dalam dan dapat mempengaruhi seseorang untuk berperilaku tertentu. Sementara motivasi ekstrinsik adalah motivasi yang didapatkan dari orang lain bukan berasal dari dalam diri orang itu sendiri. Seseorang yang memotivasi orang lain, maka motivasi yang diperolehnya berupa motivasi ekstrinsik.

Pendapat senada dikemukakan Nawawi (2007: 351), di mana fungsi motivasi dibagi dalam tiga macam yaitu: 
(1) motivasi sebagai penggerak bagi manusia sebagaimana bahan bakar pada kenderaan, (2) motivasi merupakan pengatur dalam memilih alternatif di antara dua atau lebih kegiatan dengan memperkuat suatu motivasi atau memperlemah motivasi yang lain, sehingga seseorang akan melakukan aktivitas atau meninggalkan aktivitas yang lain dan (3) motivasi merupakan pengatur arah atau tujuan dalam melakukan aktivitas. Dengan perkataan lain seseorang akan memilih dan berusaha untuk mencapai tujuan pada sistem yang memberikan motivasi tinggi bukan mewujudkan tujuan pada sistem dengan motivasi lemah.

Berkaitan dengan fungsi menggerakkan, motivasi akan menjadi sumber kekuatan bagi manusia sebagai makhluk hidup yang memiliki daya gerak yang mencakup seluruh aktivitas mental yang dirasakan atau dialami dan memberikan kondisi sehingga terjadi perilaku tertentu.

Sebagai fungsi pengatur motivasi memiliki peran ganda yakni pengatur dalam memilih alternatif kegiatan dan pengatur dalam memilih tujuan. Peran sebagai pengatur alternatif diwujudkan dalam bentuk memilih aktivitas mana yang memiliki motivasi yang lebih besar dari berbagai alternatif aktivitas yang ada secara bersamaan. Sedangkan hubungannya dengan peran motivasi sebagai pengatur memilih tujuan dimanifestasikan dalam bentuk memilih aktivitas mana yang sesuai dengan tujuan pribadi seseorang.

Penelitian-penelitian dibidang motivasi telah banyak menghasilkan teori-teori motivasi yang tidak saja menjadi milik kaum akademis saja namun banyak dimanfaatkan untuk kepentingan manajemen industri saat itu. Satu di antaranya adalah teori motivasi yang dipopulerkan oleh Abraham Maslow yang dikenal sebagai Abraham Maslow's Hierarchy of Needs Theory (Teori Hirarki Kebutuhan Abraham Maslow). Menurut teori ini pada dasarnya manusia memiliki lima tingkatan (hirarki) kebutuhan.
Pertama, kebutuhan fisik (physiological needs) adalah kebutuhan utama yang paling mendasar bagi manusia seperti: makan, udara, istirahat,seks, perumahan, pakaian dan sebagainya. Kebutuhan ini adalah kebutuhan primer untuk memper-tahankan hidup. Kedua, kebutuhan akan rasa aman (safety needs) merupakan kebu-tuhan akan perlindungan, rasa aman dan terbebas dari ketakutan. Termasuk dalam kebutuhan ini adalah penjagaan dari ancaman fisik, mental dan sebagainya. Ketiga, kebutuhan sosial (social needs) merupakan kebutuhan yang bersifat sosial, hubungan antar manusia seperti kasih sayang, cinta, rasa memiliki dan dimiliki, persahabatan dan seterusnya, sebagaimana kita lihat pada gambar 4 hirarki.

Sumber: Derek Torrington, Jane Weightman dan Kirsty John, Effective Management People and Organization (London: Prentice-Hall, 2009), p. 247

Teori klasik berikutnya adalah Teori $\mathrm{X}$ dan $\mathrm{Y}$ yang dipelopori oleh Douglas McGregor seorang tutor besar manajemen pada lembaga Teknik Massachussets (Massachussetss institute of Technology). Melalui teori yang termuat dalam bukunya The Human State of Enterprise, Gregor (2002: 51-52) membedakan sifat manusia menjadi dua, yaitu: Pertama, dasarnya perilaku negatif yang disebut Teori $\mathrm{X}$ dengan asumsi bahwa pamong belajar tak suka bekerja, malas menghindar dari tanggung jawab dan menunjukan sedikit ambisi dalam bekerja, oleh karena itu pamong belajar yang demikian harus diawasi. Kedua, dasarnya perilaku positif yang disebut Teori $\mathrm{Y}$ dengan asumsi bahwa pamong belajar memandang kerja sebagai sesuatu yang natural seperti istirahat dan bermain, menerima tanggung jawab, memilih arah diri dan mampu membuat keputusan-keputusan yang inovatif. 


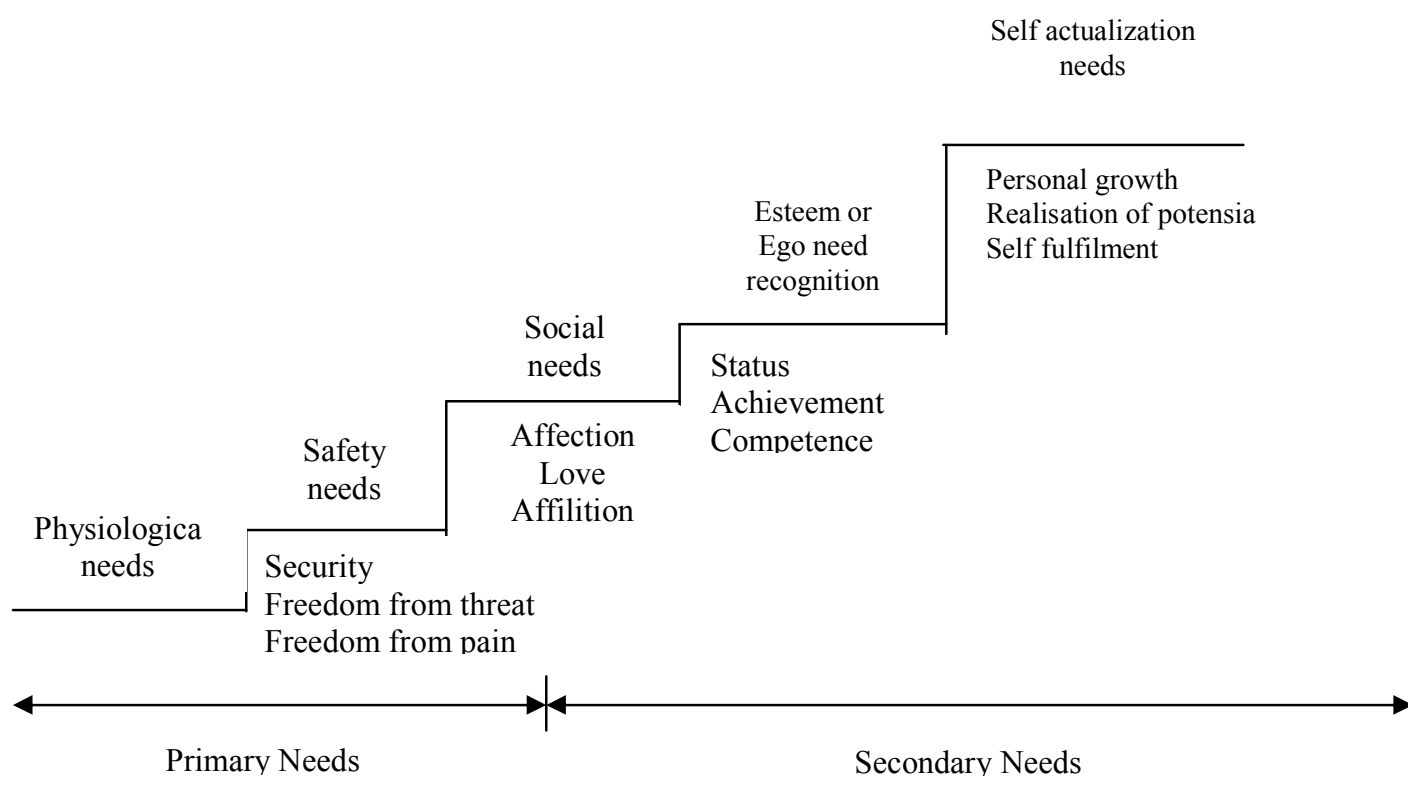

Gambar 4. Hirarki Teori Kebutuhan Maslow

Dengan memandang teori $\mathrm{X}$ yang mengasumsikan bahwa manusia adalah memiliki sifat yang statis maka menurut teori ini dalam memotivasi seseorang harus dilakukan dengan cara-cara yang ketat, cenderung dengan paksaan supaya mereka mau bekerja dengan sungguhsungguh. Jenis motivasi yang diterapkan adalah jenis motivasi negatif di mana hukuman diterapkan secara tegas dan bersifat koreksif. Sementara itu menurut teori $\mathrm{Y}$ yang mangasumsikan bahwa manusia memiliki sifat-sifat yang positif maka dalam pemberian motivasi dapat dilakukan dengan pemberdayaan pamong belajar, kerja sama pemberian tanggung jawab.

\section{METODOLOGI PENELITIAN}

Penelitian ini dilaksanakan pada Balai Kegiatan Belajar Masyarakat (BPKB) Provinsi Gorontalo selama 4 bulan yaitu mulai bulan Juli sampai dengan Oktober 2013.

Metode yang digunakan dalam penelitian ini adalah metode Survei dengan teknik korelasional. Metode ini dipilih untuk mencapai tujuan penelitian, yaitu dengan mengkorelasikan; (a) skor data keterlibatan pamong belajar dalam pengambilan keputusan dengan motivasi kerja pamong, (b) skor data komunikasi interpersonal dengan motivasi kerja pamong dan (c) skor data keterlibatan pamong dalam pengambilan keputusan dan komunikasi interpersonal dengan motivasi kerja pamong belajar.

Konstelasi hubungan dari ketiga variabel penelitian yang dikorelasikan, digambarkan sebagai berikut:

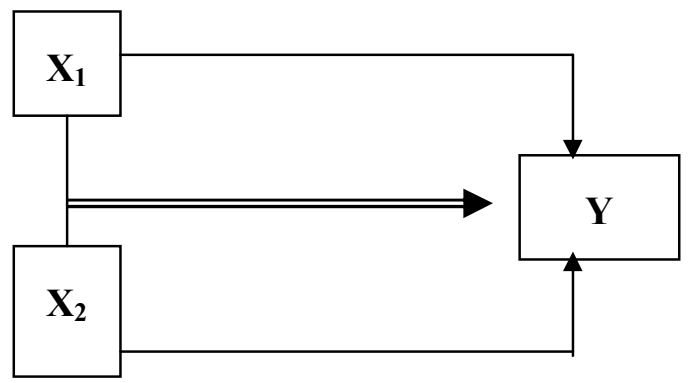

Gambar 6. Konstelasi Hubungan Variabel Penelitian

\section{Keterangan:}

$\mathrm{X}_{1}$ : Keterlibatan pamong belajar dalam Pengambilan Keputusan

$\mathrm{X}_{2}$ : Komunikasi Interpersonal pamong belajar

Y : Motivasi Kerja pamong belajar 
Populasi dalam penelitian ini adalah pamong belajar di BPKB dengan jumlah populasi secara keseluruhan adalah 47 orang. Sampel adalah seluruh populasi yakni 47 orang pamong belajar dengan menggunakan teknik total sampling atau sampel jenuh. Sebelum digunakan untuk menguji hipotesis penelitian, skor data hasil penelitian terlebih dahulu dilakukan uji persyaratan yang meliputi uji normalitas dan uji homogenitas. Uji normalitas antara lain dimaksudkan untuk menentukan jenis statistik yang akan digunakan menguji hipotesis penelitian. Apabila datanya berdistribusi normal maka pengujian selanjutnya dilakukan dengan menggunakan statistik parametrik, sedangkan pada keadaan lain (tidak normal) menggunakan statistika non parametrik. Normalitas data diuji dengan Untuk uji normalitas data digunakan dua buah uji yaitu uji Kolmogorov-Smirnov dan Shapiro-Wilks. Perhitungan kedua uji tersebut dilakukan dengan menggunakan program SPSS versi 18.00.

\section{HASIL PENELITIAN DAN PEMBA- HASAN}

\section{Motivasi kerja Pamong (Y)}

Berdasarkan hasil out put analisis deskriptif dengan program SPSS versi 18.0 (terlampir) untuk data motivasi kerja pamong belajar diperoleh hasil sebagai berikut :

1) $\mathrm{N}$ atau jumlah data yang valid (sah untuk diproses) adalah 47.

2) Mean atau rata-rata skor motivasi kerja pamong adalah 158,12 dengan standar error 1,54. Pada tingkat kepercayaan $95 \%$ dengan standar error of mean 1,54 maka diperkirakan besar rata-rata skor motivasi kerja pamong populasi yang diperkirakan dari sampel adalah $158,12 \pm(2 \times 1,54)=$ skor 155,04 sampai dengan skor 161,2.

3) Median atau titik tengah data jika semua data diurutkan dan dibagi dua sama besar. Angka median 159,00 menunjukkan bahwa $50 \%$ skor motivasi kerja pamong belajar adalah 159,00 ke atas dan 50\%-nya adalah 148,00 ke bawah.

4) Standar deviasi adalah 10,62 . Untuk itu pada tingkat kepercayaan 95\% dengan standar deviasi 10,62 maka dispersi rata-rata dari sampel adalah $158,12 \pm$ $(2 \times 10,62)=$ skor 136,88 sampai dengan skor 179,36.

5) Ukuran skeweness adalah 0,40. Untuk penilaian, nilai tersebut diubah ke angka rasio. Rasio skeweness adalah nilai skeweness atau standar error skeweness. Jadi dengan demikian rasio skeweness $=0,40 / 0,34=2,17$. Sebagai pedoman, jika rasio skeweness berada di luar -2 sampai dengan +2 , maka distribusi data adalah normal. Oleh karena $-6,88$ terletak pada daerah luar 2 dan +2 maka dapat disimpulkan bahwa data motivasi kerja pamong belajar adalah normal.

6) Data minimum adalah skor 128 dan data maksimum adalah skor 190 .

7) Range adalah data maksimum - data minimum adalah skor 62 .

Skor motivasi kerja pamong divisualisasikan dalam histogram berikut.

Distribusi frekuensi variabel motivasi kerja pamong diperoleh hasil perhitungan banyak kelas pada variabel Y sebanyak 6 kelas dengan jarak kelas 10 . Berikut ini disajikan tabel dan grafik variabel motivasi kerja pamong (Y) sebagai berikut .

Tabel 4.1. Distribusi Frekuensi Variabel

\begin{tabular}{|c|c|c|c|c|}
\hline \multicolumn{5}{|c|}{ Motivasi Kerja (Y) } \\
\hline & terval & Frekuensi & Frekuensi & _Frekuensi \\
\hline \multicolumn{2}{|c|}{ Kelas } & Absolut & Relatif \% & Komulatif \\
\hline 128 & & 1 & 2.13 & 2.13 \\
\hline 139 & -1 & 10 & 21.28 & 23.40 \\
\hline 150 & 16 & 16 & 34.04 & 57.45 \\
\hline 161 & 1 & 17 & 36.17 & 93.62 \\
\hline 172 & 18 & 2 & 4.26 & 97.87 \\
\hline 183 & $-\quad 1 S$ & 1 & 2.13 & 100.00 \\
\hline \multicolumn{2}{|c|}{ Jumlah } & 47 & 100.00 & \\
\hline
\end{tabular}


Dari tabel di atas tercermin bahwa frekuensi relatif paling rendah sebesar $2,13 \%$ responden memiliki motivasi kerja yang berada pada interval skor $128-138$ dan 183 - 193, frekuensi relatif paling paling tinggi $36,17 \%$ responden memiliki motivasi kerja yang berada pada interval skor 161-171, Untuk memperjelas penyajian distribusi frekuensi variabel motivasi kerja pamong belajar (Variabel Y) tersebut, disajikan pula grafik batang seperti pada gambar sebagai berikut :

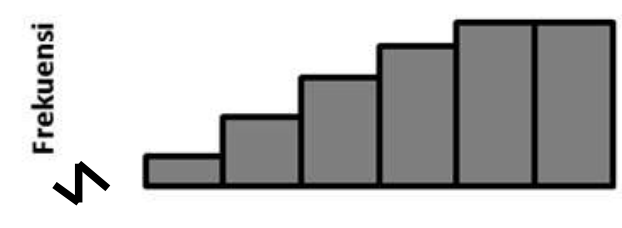

Gambar 4. 1. Histogram Skor Variabel motivasi kerja pamong belajar $(\mathrm{Y})$

Berdasarkan gambar 4.1 skor teoritik bergerak dari 128 terendah bergerak sampai 190 skor tertinggi dengan skor median teoritiknya 95. Hasil penelitian secara empirik skor terendah128, skor tertinggi 190 Berarti motivasi kerja pamong belajar dalam penelitian ini secara relatif dikatagorikan tinggi.

\section{Keterlibatan pamong dalam pengambilan keputusan}

Berdasarkan hasil out put analisis deskriptif dengan program SPSS versi 18.0 (terlampir) untuk data keterlibatan pamong belajar dalam pengambilan keputusan diperoleh hasil sebagai berikut:

a. $\mathrm{N}$ atau jumlah data yang valid (sah untuk diproses) adalah 47.

b. Mean atau rata-rata skor keterlibatan pamong belajar dalam pengambilan keputusan adalah 135,74 dengan standar error 0,99. Pada tingkat kepercayaan $95 \%$ dengan standar error of mean 0,99 maka diperkirakan besar rata-rata skor keterlibatan pamong belajar dalam pengambilan keputusan populasi yang diperkirakan dari sampel adalah $135,74 \pm(2 \times 0,99)=$ skor 133,76 sampai dengan skor 137,72.

c. Median atau titik tengah data jika semua data diurutkan dan dibagi dua sama besar. Angka median 136,00 menunjukkan bahwa 50\% skor keterlibatan pamong belajar dalam pengambilan keputusan adalah 136,00 ke atas dan 50\%-nya adalah 136,00 ke bawah.

d. Standar deviasi adalah 6,83. Untuk itu pada tingkat kepercayaan 95\% dengan standar deviasi 6,83 maka dispersi ratarata dari sampel adalah $135,74 \pm(2 \mathrm{x}$ $6,83)=$ skor 122,08 sampai dengan skor 149,4 .

e. Data minimum adalah skor 123,00 dan data maksimum adalah skor 148

f. Range adalah data maksimum - data minimum adalah skor 25

Distribusi frekuensi variabel keterlibatan pamong belajar dalam mengambil keputusan diperoleh hasil perhitungan banyak kelas pada variabel X1 sebanyak 6 kelas dengan jarak kelas 3 . Berikut ini disajikan tabel dan grafik variabel keterlibatan pamong belajar dalam mengambil keputusan sebagai berikut .

Tabel 4.2. Distribusi Frekuensi Variabel Keterlibatan pamong belajar Dalam Mengambil Keputusan (X1)

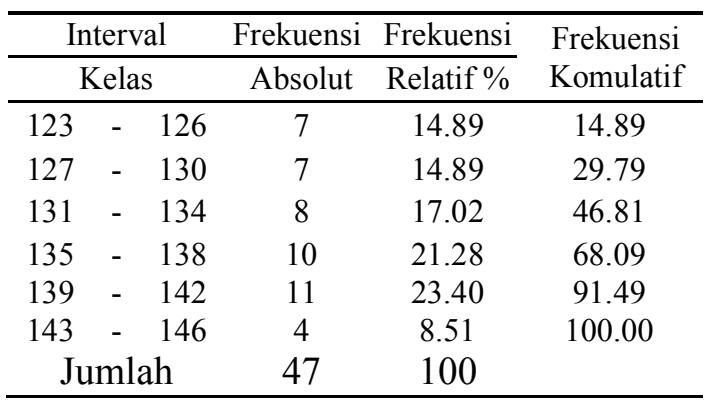

Dari tabel di atas tercermin bahwa frekuensi relatif paling rendah sebesar $8,51 \%$ responden memiliki keterlibatan 
dalam mengambil suatu keputusan yang berada pada interval skor 143-146, frekuensi relatif paling paling tinggi $23,40 \% \%$ responden memiliki keterlibatan dalam mengambil keputusan yang berada pada interval skor 139-142, Untuk memperjelas penyajian distribusi frekuensi variabel keterlibatan pamong dalam mengambil keputusan (Variabel X1) tersebut, disajikan pula grafik batang seperti pada gambar sebagai berikut :

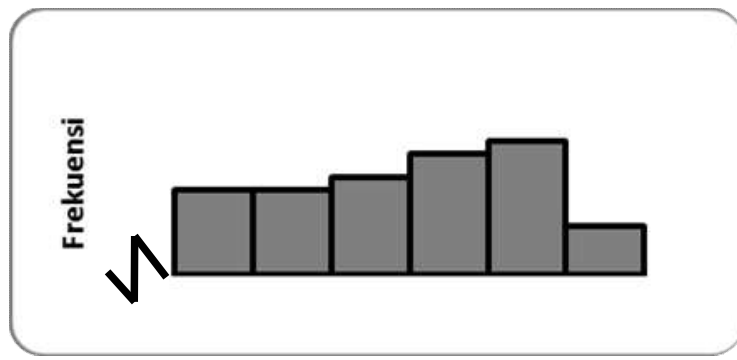

Gambar 4.2. Histogram Skor keterlibatan pamong belajar dalam mengambil keputusan (X1)

Berdasarkan gambar 4.2 skor teoritik bergerak dari 123 terendah bergerak sampai 148 skor tertinggi dengan skor median teoritiknya 80 . Hasil penelitian secara empirik skor terendah 123, skor tertinggi 148 Berarti keterlibatan pamong belajar dalam mengambil keputusan (X1) dalam penelitian ini secara relatif dikatagorikan tinggi karena skor terendah empirik lebih tinggi dari median teoritik.

\section{Komunikasi Interpersonal}

Berdasarkan hasil out put analisis deskriptif dengan program SPSS versi 18.0 (terlampir) untuk data komunikasi interper-sonal diperoleh hasil sebagai berikut:

a. $\mathbf{N}$ atau jumlah data yang valid (sah untuk diproses) adalah 47

b. Mean atau rata-rata skor komunikasi interpersonaladalah 145,14 dengan standar error 1,32. Pada tingkat kepercayaan $95 \%$ dengan standar error of mean 1,32 maka diperkirakan besar rata-rata skor komunikasi interpersonal populasi yang diperkirakan dari sampel adalah $145,14 \pm(2 \times 1,32)=$ skor 142,5 sampai dengan skor 147,78

c. Median atau titik tengah data jika semua data diurutkan dan dibagi dua sama besar. Angka median 145,00 menunjukkan bahwa $50 \%$ skor motivasi kerja pamong belajar adalah 145,00 ke atas dan 50\%-nya adalah 156,00 ke bawah.

d. Standar deviasi adalah 9,07. Untuk itu pada tingkat kepercayaan 95\% dengan standar deviasi 9,07 maka dispersi ratarata dari sampel adalah $145,14 \pm(2 \mathrm{x}$ $9,07)=$ skor 127,00 sampai dengan skor 163,28

e. Ukuran skeweness adalah $-0,447$. Untuk penilaian, nilai tersebut diubah ke angka rasio. Rasio skeweness adalah nilai skeweness atau standar error skeweness. Jadi dengan demikian rasio skeweness $=-0,447 / 0,347=-1,288$. Sebagai pedoman, jika rasio skeweness berada di daerah -2 sampai dengan +2 , maka distribusi data adalah normal. Oleh karena -1,288 terletak pada daerah -2 dan +2 , maka dapat disimpulkan bahwa data komunikasi interpersonal adalah berdistribusi normal.

f. Data minimum adalah skor 124,00 dan data maksimum adalah skor 160

g. Range adalah data maksimum - data minimum adalah skor 36

Distribusi frekuensi variabel komuni-kasi interpersonal diperoleh hasil perhi-tungan banyak kelas pada variabel X2 sebanyak 6 kelas dengan jarak kelas 6. Berikut ini disajikan tabel dan grafik variabel Komunikasi Interpersonal seba-gai berikut .

Tabel 4.3. Distribusi Frekuensi Variabel Komunikasi Interpersonal (X2)

\begin{tabular}{cccccc}
\hline \multicolumn{2}{c}{ Interval } & Frekuensi & Frekuensi & Frekuensi \\
\cline { 1 - 4 } \multicolumn{2}{c}{ Kelas } & Absolut & Relatif \% & Komulatif \\
\hline 124 & - & 130 & 3 & 6.38 & 6.38 \\
131 & - & 137 & 6 & 12.77 & 19.15 \\
138 & - & 144 & 13 & 27.66 & 46.81 \\
145 & - & 151 & 12 & 25.53 & 72.34
\end{tabular}




\begin{tabular}{ccccc}
$152-158$ & 10 & 21.28 & 93.62 \\
$159-165$ & 3 & 6.38 & 100.00 \\
Jumlah & 47 & 100.00 & \\
\hline
\end{tabular}

Dari tabel di atas tercermin bahwa frekuensi relatif paling rendah sebesar $6,38 \%$ responden yang berada pada interval skor 124-130 dan 159-165, frekuensi relatif paling paling tinggi $27,66 \%$ berada pada interval skor 138144, Untuk memperjelas penyajian distribusi frekuensi variabel Komunikasi Interpersonal (Variabel X2) tersebut, disajikan pula grafik batang seperti pada gambar sebagai berikut :

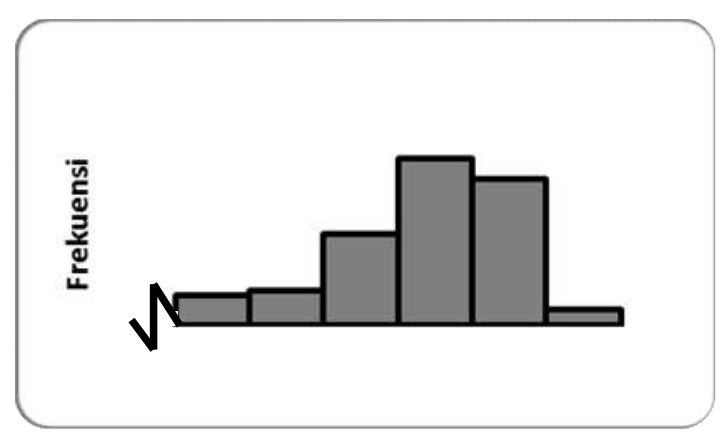

Gambar 4.3. Histogram Skor Komunikasi Interpersonal (X2)

Berdasarkan gambar 4.3 skor teoritik bergerak dari 124 terendah bergerak sampai 160 skor tertinggi dengan skor median teoritiknya 82,5 . Hasil penelitian secara empirik skor terendah 124, skor tertinggi 160 Berarti Komunikasi Interpersonal (X2) dalam penelitian ini secara relatif dikata-gorikan tinggi karena skor terendah empirik lebih tinggi dari median teoritik.

Interpretasi hasil penelitian mengacu pada hasil pengujian tiga hipotesis penelitian, yaitu; (a) hubungan Keterlibatan pamong belajar dalam Pengambilan Keputusan dengan Motivasi Kerja pamong belajar, (b) hubungan Komunikasi Interpersonal dengan Motivasi Kerja pamong belajar, dan (c) hubungan Keterlibatan pamong belajar dalam Pengambilan Keputusan dan Komunikasi Interpersonal dengan Motivasi Kerja pamong belajar.

\section{Interpretasi Hubungan Keterlibatan Pamong dalam Pengambilan Kepu- tusan dengan Motivasi Kerja}

Dari persamaan regresi yang diperoleh $\hat{Y}=13,510+1,065 \mathrm{X}_{1}$, jelas bahwa setiap kenaikan skor Keterlibatan pamong belajar dalam Pengambilan Keputusan diikuti oleh naiknya skor Motivasi Kerja atau makin tinggi Keterlibatan pamong belajar dalam Pengambilan Keputusan, makin tinggi Motivasi Kerja.

Ditinjau dari nilai koefisien determinasi $\left(r^{2}\right)=0,470$, dapat dipahami bahwa sebesar $47 \%$ variasi Motivasi Kerja pamong belajar dapat dijelaskan oleh Keterlibatan pamong dalam Pengambilan Keputusan. Sedangkan sebesar 53\% dijelaskan oleh faktor lain. Hal ini menguatkan argumentasi bahwa Motivasi Kerja pamong ditentukan oleh banyak faktor di antara dari faktor tersebut adalah Keterlibatan pamong belajar dalam Pengambilan Keputusan. Keterlibatan pamong dalam Pengambilan Keputusan pamong secara nyata atau sebesar $47 \%$ dapat meningkatkan Motivasi Kerja.

Walaupun Keterlibatan pamong belajar dalam Pengambilan Keputusan memiliki hubungan yang relatif kecil yaitu sebesar 47\% dengan Motivasi Kerja pamong, namun secara statistik telah diperoleh bahwa hubungan itu sangat signifikan sehingga tidak dapat diabaikan.

\section{Interpretasi Hubungan Komunikasi} Interpersonal dengan Motivasi Kerja

Dari persamaan regresi yang diperoleh $\hat{Y}=91,986+0,456 \mathrm{X}_{2}$ maka setiap kenaikan skor Komunikasi Interpersonal diikuti oleh naiknya skor Motivasi Kerja atau makin tinggi Komunikasi Interpersonal, makin tinggi Motivasi Kerja pamong belajar. Ditinjau dari nilai koefisien determinasi $\left(r^{2}\right)=0,152$ dapat dipahami bahwa sebesar $15,2 \%$ variasi Motivasi Kerja dapat dijelaskan oleh Komunikasi Interpersonal, Sedangkan sebesar 84,8\% dijelaskan oleh faktor lain. Hal ini dapat menjadi dasar argumentasi bahwa Motivasi Kerja ditentukan oleh 
banyak faktor di antara dari faktor tersebut adalah Komunikasi Interpersonal. Komunikasi Interpersonal secara nyata atau sebesar $15,2 \%$ dapat meningkatkan Motivasi Kerja.

Walaupun Komunikasi Interpersonal memiliki hubungan yang relatif kecil yaitu sebesar 15,2\% dengan Motivasi Kerja, namun secara statistik telah diperoleh bahwa hubungan itu signifikan sehingga tidak dapat diabaikan.

\section{Interpretasi Hubungan Keterlibatan Pamong dalam Pengambilan Kepu- tusan dan Komunikasi Interpersonal dengan Motivasi Kerja.}

Dari persamaan regresi yang diperoleh $\hat{Y}=10,494+1,026 \mathrm{X}_{1}+0,058 \mathrm{X}_{2}$ jelas bahwa setiap kenaikan skor Keterlibatan pamong belajar dalam Pengambilan Keputusan dan Komunikasi Interpersonal, diikuti oleh naiknya skor Motivasi Kerja atau makin tinggi Keterlibatan pamong belajar dalam Pengambilan Keputusan dan Komunikasi Interpersonal, maka makin tinggi Motivasi Kerja.

Dengan mengacu pada ukuran nilai koefisien korelasi berkisar dari -1 sampai dengan 1, dan dengan memahami bahwa koefisien korelasi positif memiliki nilai; (a) 0,00 - 0,20 tidak berkorelasi, (b) 0,21 0,40 berkorelasi lemah, (c) $0,41-0,60$ berkorelasi sedang, (d) $0,61-0,80$ berkorelasi kuat, dan (e) $0,81-1,00$ berkorelasi tinggi (Hajar, 1999: 241), maka korelasi Keterlibatan pamong belajar dalam Pengambilan Keputusan dengan Motivasi Kerja $r_{\mathrm{y} 1}=0,686$, berkorelasi sedang, sedangkan korelasi Komunikasi Interpersonal dengan Motivasi Kerja $\mathrm{r}_{\mathrm{y} 2}=0,389$ berkorelasi lemah. Gabungan dari Keterlibatan pamong belajar dalam Pengambilan Keputusan dan Komunikasi Interpersonal menunjukkan koefisien sebesar 0,687. Artinya kedua faktor, (a) Keterlibatan pamong dalam Pengambilan Keputusan, dan (b) Komunikasi Interpersonal secara bersama-sama dapat menentukan Motivasi Kerja.
Secara bersama-sama Keterlibatan pamong belajar dalam Pengambilan Keputusan dan Komunikasi Interpersonal berkorelasi dengan Motivasi Kerja memiliki koefisien korelasi sebesar $R_{y .12}=0,687$. Prosentase variasi Motivasi Kerja yang dapat dijelaskan secara bersama-sama oleh Keterlibatan pamong belajar dalam Pengambilan Keputusan dan Komunikasi Interpersonal, sebesar 68,7\%. Hasil ini diperoleh dari besar koefisien determinasi korelasi multipel $\left(\mathrm{r}^{2}\right)$ sebesar 0,472. Dengan demikian 47,2\% variasi Motivasi Kerja, dijelaskan oleh faktor lain.

Dari beberapa harga koefisien di atas terlihat bahwa, keeratan hubungan antar variabel muncul dalam dua bentuk yaitu hubungan lemah dan hubungan sedang.

\section{SIMPULAN}

Dari hasil analisa data dan uji hipotesis disimpulkan bahwa motivasi kerja pamong belajar dapat ditingkatkan dengan meningkatkan keterlibatan pamong belajar dalam pengambilan keputusan dengan komunikasi interpersonal.

\section{DAFTAR PUSTAKA}

Amstrong, Michael. Seri Pedoman Manajemen Sumber Daya Manusia, terjemahan Sofyan Cikmat dan Haryanto. Jakarta: Elex Media Komputindo, 2009.

Anoraga, Panji. Psikologi Kerja. Jakarta: Rineka Cipta, 2002.

Baron, Robert A.. Behavior in Organizations. Boston: Allyn and Bacon, 2003.

Brown, Warren W. dan Dennis J. Moberg. Organization Theory and Management. New York: John Wiley and Sons, 2000.

Cascio, Wayne F. Managing Himan Resources. Naw York: McGrawHill, Inc., 2005.

Curtis, Dan B., James J. Floyd and Jerry L. Winsor. Bussines and Profes-sional Communication. New York: Harper Collins Publisher, 2002. 
Davis, Keith dan Newstrom. Perilaku dalam Organisasi, Jilid I. Jakarta: Erlangga, 2000.

Effendi, Onong Uchjana. Dimensi-dimensi Komunikasi. Bandung: Penerbit Alumni, 2006.

Gomes-Mejia, Luis R., David B. Balkin dan Robert L. Cardy. Managing Human Resources. New Jersey: Prentice-Hall, Inc., 2008.

Gouran, Dennis S., Larry D. Miller dan William E. Wiethoff. Mastering Communication. Boston: Allyn and Bacon, 2002.

Hasibuan, Melayu S.P. Organisasi dan Motivasi. Jakarta: Bumi Aksara, 2006

Hellriegel, Don dan John W. Slocum. Manajement. Ccanada: AddisonWesley Publishing Company, 2009.

Hersey, Paul. dan Kenneth H. Blanchard. Management of Organizational Behavior. New Jersey: Prentice-Hall, 2008.

Huitt, W. Motivation, 2008, (http://Chiron.valdosta,edu/Whuitt)

Koonz, Harold, Cyril O'Donnel dan Heinz Wihrich, Management. New York: Mc Graw-Hill, 2004.

Longececker, Justin G. Principles of Management and Organizational Behavior. Ohio: Charles E. Merril Publishing Co., 1969.

Nawawi, Hadari. Manajemen Sumber Daya Manusia untuk Bisnis yang Kompetitif. Yogyakarta: Gadjah Mada University Press, 2007.

Pareek, Udai. Perilaku Organisasi. Jakarta: PT.Pustaka Binaman Pressindo, 2006.

Pranesti, Gregoria dan Roek Hudin. Analisis Korelasi Gaya Kepemimpinan Dengan Penerapan Penganggaran Partisipatif. 2002.

(http://www.fe.unibraw.ac.id/TemaVolII/Pranesti-Roekhudin)

Rakhmat, Jalaluddin. Psikology Komunikasi. Bandung: Remaja Rosda Karya, 2008
Sastropoetro, Santoso. Pendapat Publik, Pendapat Umum, dan Pendapat Khalayak dalam Komunikasi Sosial. Bandung: Remaja Rosda Karya, 2000.

Scanlon, Burt dan Bernard. Management and Organizational Behavior. New York: John Wilwy \& Sons, 2003.

Schermerhorn, John R. Management .New York: John Wiley \& Sons, Inc., 2006.

Seiler, William J. Introduction To Speech Communication. New York: Harper Collins Publisher, 2002.

Siagian, Sondang P. Teor Pengembangan Orgnaisasi. Jakarta: Bumi Aksara, 2005.

Smyle, Mark A. Instructional Outcomes of school-Based Participative Decision Making. Chicago: Educational Evaluation and Policy Analysis, Vol. 18, No. 3, 2006.

Steers, Richard M. and Lyman W. Porter. Motivation and Work Behavior,. Singapore: Mc. Graw-Hill, 2005.

Stoner, James A.F., R. Edward Freeman and Daniel R. Gilbert J.R. Manajement. Terjemahan Alexander Sindoro. Jakarta: Prenhallindo, 2006.

Sudarmo, Indriyo Gito dan Nyoman Sudita. Perilaku Keorganisasian. Yogya-karta: BPFE, 2000.

Sumidjo, Wahjo. Kepemimpinan dan Motivasi. Jakarta: Ghalia Indonesia, 2002.

Supratiknya. Kominikasi Antarprobadi. Yogyakarta: Kanisius, 2005.

Sutarto. Dasar-dasar Organisasi. Yogyakarta: Gadjah Mada University Press, 2003.

Thoha, Mifta. Perilaku Organisasi. Jakarta: Raja Grafindo Persada, 2004.

Tubbs, Stewart L. dan Sylvia Moss. Human Communication, terjemahan Deddy Mulyana dan Gembirasari. Bandung: Remaja Rosda Karya, 2006. 
Psympathic, Jurnal Ilmiah Psikologi Juni 2014, Vol. 1, No.2, Hal : 130 - 149

Umar, Husein. Riset Sumber Daya

Manusia dalam Organisasi. Jakarta: PT.

Gramedia, 2008. 